\title{
HYPOTHESIS
}

\section{Is fibrosing colonopathy an immune mediated disease?}

\author{
Julia Lee, Wan Ip, Peter Durie
}

\begin{abstract}
Fibrosing colonopathy, a recently described complication of patients with cystic fibrosis, manifests clinically approximately 7-12 months after starting high dose pancreatic enzyme treatment. Although the pathogenesis of fibrosing colonopathy is unknown, it is highly correlated with pancreatic enzyme dose. In this study, immune mediated factors which may be associated with fibrosing colonopathy were explored. Sera from 14 patients with cystic fibrosis and meconium ileus were collected at diagnosis and then longitudinally for four to five years after enzyme treatment. Sera were analysed for total IgG and antiporcine trypsin IgG using an ELISA assay. Before enzyme treatment, serum antiporcine trypsin IgG concentrations were negligible, at 2.9 (SD $0.3) \mu \mathrm{g} / \mathrm{ml}$. Thirteen patients $(93 \%)$ developed a significant antibody response to porcine trypsin after starting enzyme treatment, reaching a peak concentration of $69.4(20.1) \mu \mathrm{g} / \mathrm{ml} \mathrm{7-12}$ months after the introduction of enzymes. Since peak IgG concentrations coincided with published reports of time of onset of symptoms of fibrosing colonopathy, local injury by protease or by immune mediated mechanisms may be responsible for the pathological changes in this iatrogenic disease.

(Arch Dis Child 1997;77:66-70)
\end{abstract}

Gastroenterology and Nutrition, The

Research Institute,

Hospital for Sick

Children, Department

of Paediatrics,

University of Toronto,

Toronto, Ontario,

Canada

J Lee

W Ip

P Durie

Correspondence to:

Dr Peter Durie, Division of

Gastroenterology and

Nutrition, Hospital for Sick

Children, 555 University

Avenue, Toronto, Ontario

M5G 1X8, Canada.

Accepted 17 March 1997 1970 s, enzymes were developed composed microspheres or microtablets coated with an acid resistant film. Theoretically, the acid resistant coating protects the enzymes from gastric inactivation, but following entry into the duodenum, the coating dissolves, releasing intact enzymes to initiate digestion. Despite the theoretical advantage of these products, significant numbers of patients with cystic fibrosis continued to experience severe maldigestion. ${ }^{45}$ In 1991, high strength pancreatic enzymes were marketed (> 20000 units of lipase). It was argued that fewer capsules would be more convenient and might improve patient compliance.

In 1994, Smyth and colleagues described a new complication affecting cystic fibrosis patients. ${ }^{6}$ Five young males with cystic fibrosis developed severe fibrotic narrowing of the ascending colon, requiring surgical resection. Subsequently, numerous additional reports emanated from cystic fibrosis centres in the United Kingdom, other parts of Europe, and the USA. ${ }^{7-12}$ The common factor among the majority of these children, all of whom were under 14 years of age, appeared to be conversion to high potency enzyme supplements approximately 12 months before the onset of symptoms. It was also noted that the total daily enzyme dosage was extremely high, ranging from 6500 to $58000 \mathrm{U}$ lipase $/ \mathrm{kg} / \mathrm{meal} .{ }^{12}$ Pathologically, the colon was characterised by mild to moderate mucosal inflammation and fibrotic thickening of the submucosa. ${ }^{13}$ In a significant proportion of cases, eosinophilic infiltration of the colon was also evident. Some investigators reported an area of focal fibrosis, predominantly in the ascending colon, ${ }^{6}$ while others described severe pancolonic involvement, with foreshortening and narrowing of the luminal diameter. ${ }^{14}$ The term 'fibrosing colonopathy' has been coined to describe both the presymptomatic and symptomatic lesions. ${ }^{15}$

In 1995, an epidemiologic case-control study conducted in the United Kingdom showed a strong dose related association between high strength pancreatic enzyme preparations and the risk of developing fibrosing colonopathy. ${ }^{16}$ This study also suggested that other factors, such as the formulation of the coating material, may be important in the aetiopathogenesis of fibrosing colonopathy. However, a larger epidemiological study among cystic fibrosis care centres in the USA 
showed that enzyme dose alone was strongly associated with the risk of developing fibrosing colonopathy. ${ }^{17}$ Specifically, the American casecontrol study failed to show an increased risk of fibrosing colonopathy attributable to product brand, product potency, or the nature of the coating material.

Despite a strong epidemiological association between enzyme dosage and the risk of fibrosing colonopathy, the exact aetiopathogenesis of this complication remains undetermined. Potential aetiological factors include: toxic damage by specific pancreatic enzymes, the coating material, impurities within pancreatic extracts, or an immunologically mediated mechanism induced by ingestion of high concentrations of enzymes. A previous study in our laboratory showed that older cystic fibrosis patients receiving pancreatic enzymes had an antigenic response to ingested porcine enzymes. ${ }^{18}$ It remains possible, therefore, that young children treated with high doses of pancreatic enzymes are more susceptible to localised tissue injury or immune mediated colonic damage. Large concentrations of pancreatic proteases entering the colonic lumen could induce mucosal damage, permitting the enzymes to penetrate the submucosal layer; immune complex formation, or other immune mediated mechanisms of tissue damage could then induce the pathological changes observed in fibrosing colonopathy. To examine this possibility, we studied the temporal relation between the duration of enzyme treatment and the immune mediated response to enzymes in newly diagnosed infants with cystic fibrosis.

\section{Methods}

MATERIALS

Microtitre plates (Immulon 2, 96 well) were purchased from Dynatech Laboratories (Virginia, USA). Paranitrophenol phosphate substrate was purchased from Bio-Rad Laboratories (Ontario, Canada). Goat antihuman IgG, both conjugated and unconjugated, was purchased from Biosource International (Quebec, Canada). The microtitre plate reader was purchased from Molecular Devices Corporation (California, USA). The remaining materials were all of reagent grade.

\section{PATIENTS}

Serial serum samples were obtained from 14 patients with cystic fibrosis (six females, eight males) who developed meconium ileus at birth. The diagnosis of cystic fibrosis was established by abnormal sweat chloride levels within two months of birth; 72 hour faecal fat balance studies confirmed the presence of pancreatic insufficiency, and all subjects were started on enzyme treatment within the first few weeks of birth. Patient charts were examined to record the type and amount of porcine enzymes prescribed.

Seventy nine serial serum samples were obtained: nine at birth, eight within $0-0.5$ years of age, nine within $0.5-1$ years, seven within $1-1.5$ years, eight within $1.5-2$ years, 10 within 2-3 years, seven within 3-4 years, 15 within 4-5 years, and six after 5 years of age.
ELISA ASSAY FOR ANTIPORCINE TRYPSIN IgG Sera were assayed according to the method previously developed by Couper et al. ${ }^{18}$ This assay is specific for porcine trypsin since it does not cross react with human pancreatic trypsins to a significant degree. In brief, purified porcine trypsin, inhibited by tosyl-lysylchloromethylketone (TLCK), was adsorbed onto 96-well microtitre plates. After overnight incubation, the wells were first blocked with $1 \%$ bovine serum albumin in phosphate buffered solution (PBS-1\% BSA) and then duplicate serum samples were loaded into wells, diluted to $1: 1000$ and 1:2000, respectively. After overnight incubation, goat antihuman IgG conjugated with alkaline phosphatase was added (1:5000 in PBS-BSA), and then paranitrophenol phosphate was added to the microtitre plate. The optical density was determined at $405 \mathrm{~nm}$ after 10 minutes using a microtitre plate reader. A standard curve was constructed based on known concentrations of human IgG. The ELISA (enzyme linked immunosorbent assay) method for measuring total IgG was essentially the same as that for measuring porcine trypsin IgG. Goat antihuman IgG was adsorbed onto the wells, followed by the serum samples, diluted 1:5000 with PBS-BSA and goat antihuman IgG, conjugated with alkaline phosphatase.

DATA ANALYSIS

Data are presented as mean (SD). Significance was determined by the Student's $t$ test. Since all patients began enzyme treatment within two weeks of birth, each patient's age and the duration of enzyme therapy were considered to be synonymous.

\section{Results}

Total serum IgG varied considerably from patient to patient (range: $74.8-225 \mathrm{~g} / \mathrm{l}$ ), but values in each patient remained relatively constant both before and after the initiation of enzyme treatment (table 1). Sera collected before starting enzyme treatment showed negligible concentrations of antiporcine trypsin IgG, at $2.9(0.3) \mu \mathrm{g} / \mathrm{ml}$. Following introduction of pancreatic enzymes, however, 13 of the 14 patients developed raised concentrations of antiporcine trypsin IgG (table 1 and fig 1). Mean antiporcine trypsin IgG concentrations increased with duration of enzyme treatment, reaching peak concentrations at 7-12 months of age ( $\mathrm{p}<0.01 v$ levels at diagnosis). After $7-12$ months, there was a gradual fall in serum antiporcine trypsin IgG concentrations, but they remained significantly above pretreatment values.

Daily enzyme dose (units of protease $/ \mathrm{kg} /$ day) over the course of the study was estimated using data extracted from the clinical notes (table 2). We chose to express enzyme dose as protease units rather than lipase units, because the antibody measurements were made against trypsin. Based upon information in the product insert, each enzyme capsule (Cotazym and Cotazym ECS) contained 8000 units of lipase and 30000 units of protease. All 14 patients were on powdered enzymes (Cotazym) at diag- 
Table 1 Serum antiprocine trypsin IgG concentrations $(\mu g / m l)$. Values are means $(S D)$ and range

\begin{tabular}{llll}
\hline Age & $n$ & P-Tryp-IgG & Total IgG in $g / l \Phi$ \\
\hline Diagnosis (before enzymes) & 10 & $2.9(0.3), 1.6-4.3$ & $95.3(13.3), 41.9-130.8$ \\
1-6 months & 9 & $7.2(4.7), 1.6-40.1$ & $116.8(10.2), 85.3-150$ \\
$7-12$ months & 10 & $69.4(20.1) \dagger, 15.1-176$ & $110.5(20.9), 43.7-225$ \\
$13-18$ months & 7 & $33.3(6.4) \neq, 12.2-41$ & $112.9(22.8), 73.1-193.3$ \\
$19-24$ months & 8 & $37.1(11.8)+, 6.5-111.6$ & $142.5(10.0), 122.2-155.9$ \\
$25-30$ months & 8 & $35.51(13.0)^{\star}, 7.2-101.6$ & $132.7(6.9), 113.6-154.6$ \\
$31-36$ months & 2 & $22.04(2.56) \dagger, 19.5-24.6$ & Not done \\
$37-48$ months & 7 & $11.82(4.8)^{\star}, 2.1-39.6$ & $111.9(13.9), 61.1-159.8$ \\
$49-60$ months & 15 & $19.45(5.6)^{\star}, 3.3-73.4$ & $128.7(15.7), 72.1-218.8$ \\
$60+$ months & 6 & $17.3(9.6)^{\star}, 3.9-62.5$ & $127(47.6), 79.4-174.6$ \\
\hline
\end{tabular}

$v$ before enzymes: ${ }^{\star} \mathrm{p}<0.05 ; \mathrm{tp}<0.01 ; \neq \mathrm{p}<0.001$

\Excludes three patients whose total IgG was not measured.

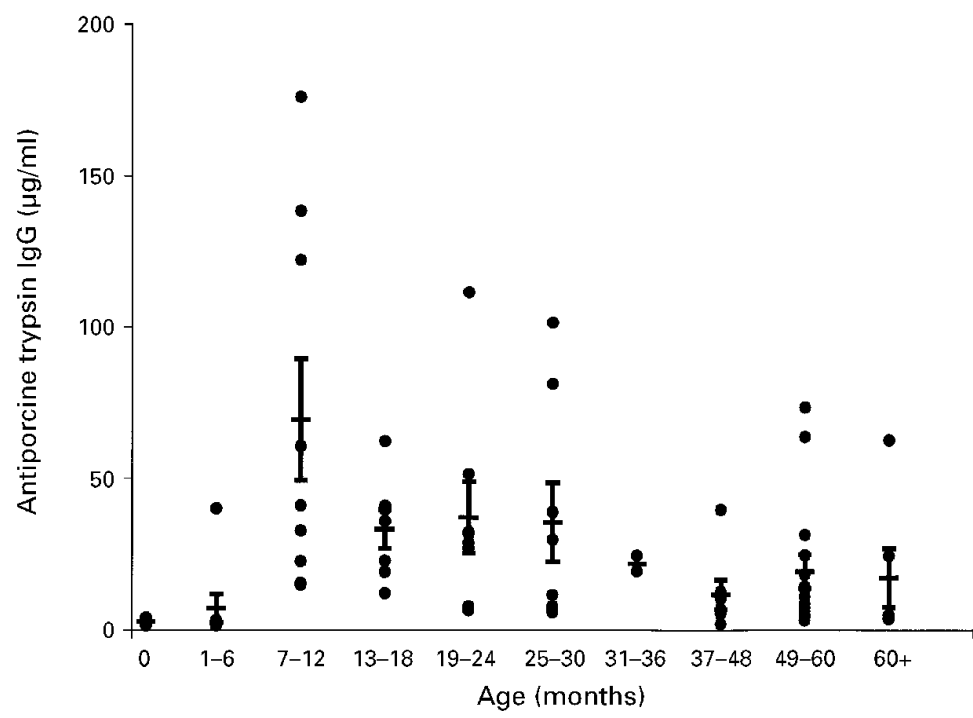

Figure 1 Individual antiporcine trypsin IgG values are plotted against age (bars show mean and $\pm 1 S D)$. Sera collected before starting enzyme treatment showed negligible concentrations of antiporcine trypsin $\operatorname{IgG}(2.9(0.3) \mu \mathrm{g} / \mathrm{ml})$. Following introduction of pancreatic enzymes, 13 of 14 patients developed raised serum concentrations of antiporcine trypsin IgG. Mean and antiporcine trypsin IgG concentrations increased with duration of treatment, reaching peak concentrations at $7-12$ months $(p<0.01 v$ pretreatment concentrations). After 7-12 months, there was a gradual decline in serum antiporcine trypsin IgG concentrations, but they remained significantly above pretreatment values.

nosis. However, six patients were receiving enteric coated enzymes (Cotazym ECS) when the peak antiporcine trypsin IgG concentrations were identified. We emphasise that the enzyme dose in $13 / 14$ patients was within the range of doses recommended in a recent consensus report on pancreatic enzyme treatment. ${ }^{15}$ Only one patient, who was referred

Table 2 Records of enzyme doses. Values are means (SD) and range

\begin{tabular}{|c|c|c|c|c|}
\hline Age & No & $\begin{array}{l}\text { Capsules containing powder, units of } \\
\text { protease/kg/day }\end{array}$ & No & $\begin{array}{l}\text { Enteric coated microspheres, } \\
\text { units of protease/kg/day }\end{array}$ \\
\hline 0 months & 9 & $\begin{array}{l}23333.3 \text { (8333.3), } 22500- \\
\quad 30000\end{array}$ & - & - \\
\hline $1-6$ months & 8 & 22500 & - & - \\
\hline $7-12$ months & 9 & $\begin{array}{l}27895.8(3088.5), 15750- \\
\quad 37500\end{array}$ & - & - \\
\hline 13-18 months & 5 & 30975 (9000.3), $10875-58500$ & 2 & $\begin{array}{l}28150(4500), 23625- \\
\quad 32625\end{array}$ \\
\hline 19-24 months & 2 & 33000 (375), 32 625-33 375 & 5 & $30862(2248)^{\star}, 6500-10000$ \\
\hline $2-3$ years & 5 & $16734(3185.7), 4545-21750$ & 4 & $\begin{array}{l}35062(52689)^{\star}, 25875- \\
48750\end{array}$ \\
\hline $3-4$ years & 1 & 27938 & 5 & $\begin{array}{l}34688(5059)^{\star}, 25500- \\
\quad 47250\end{array}$ \\
\hline $4-5$ years & 3 & 18125 (4255.5), 13 500-26 625 & 11 & $\begin{array}{l}30955(3166), 16313- \\
\quad 46500\end{array}$ \\
\hline $5+$ years & 1 & 15750 & 5 & $\begin{array}{l}26944(1257), 22969- \\
\quad 29625\end{array}$ \\
\hline
\end{tabular}

$\star$ Excludes one patient who was referred from another centre (average enzyme dose of $101250 \mathrm{U}$ protease/kg/day). to our centre after diagnosis, was receiving an enzyme dose exceeding the recommended amount-in this case it was approximately fourfold higher (101250 units protease $/ \mathrm{kg} /$ day) than the average intake in the remaining patients (26 250 units protease $/ \mathrm{kg} /$ day). The mean daily enzyme dose when the peak antiporcine trypsin IgG concentration occurred (at 7-12 months of age) was 27896 units protease $/ \mathrm{kg} /$ day, which did not differ significantly from the mean daily dose at start of treatment (23 333 units protease $/ \mathrm{kg} /$ day, $\mathrm{p}=$ $0.173)$. Thus there was no obvious correlation between the daily enzyme dose and the immunological response.

\section{Discussion}

The immune and barrier function of the intestine is immature in early postnatal life. Previous studies have shown increased intestinal uptake of intact macromolecules in young infants ${ }^{1920}$ This process may be advantageous, since it provides a mechanism for transfer of immunoglobulins from maternal milk to the newborn. In other studies ${ }^{2122}$ the presence of foreign food antigens has been detected in the systemic circulation of newborn infants after oral ingestion. A study from our laboratory also found that exocrine pancreatic insufficiency results in increased intestinal permeability to small sugars. ${ }^{23}$ Udall et al showed that ingested porcine trypsin is taken up intact into the systemic circulation of newborn infants. ${ }^{24} 25$ Kimm et al evaluated the uptake of intact protein in the proximal colon of the rabbit. ${ }^{26}$ Bovine serum albumin was absorbed intact across the colonic mucosa by a saturable energy and microtubular dependent process. Thus it is reasonable to infer that young infants with cystic fibrosis are at risk of enhanced intestinal absorption of potentially antigenic proteins, including porcine pancreatic enzymes.

Although the precise mechanisms and site of uptake have not been identified in humans, small intestinal or colonic absorption of foreign food antigens would be expected to mediate a systemic immune response. Furthermore, the colon may be more susceptible to protease damage than the small intestine. $\alpha_{1}-$ Antitrypsin, the major antiprotease in human plasma, may have a physiological role in maintaining tissue integrity within various organs. Local synthesis of $\alpha_{1}$-antitrypsin within cells of various organs may confer tissue integrity by maintaining an appropriate balance between proteases and antiproteases. Carlson et al have shown that human $\alpha_{1}$-antitrypsin mRNA is selectively expressed in the enterocytes of the small intestine, but not in the colon of transgenic mice that express the normal human $\alpha_{1}$-antitrypsin gene. ${ }^{27} \mathrm{~A}$ lack of synthesis of $\alpha_{1}$-antitrypsin within the colonic mucosa may in turn increase its susceptibility to local tissue damage by massive quantities of luminal proteases.

Theoretically, if large doses of highly antigenic porcine enzymes are ingested as $\mathrm{pH}$ resistant enteric coated microspheres, the low small intestinal $\mathrm{pH}$ that occurs in patients with 
cystic fibrosis ${ }^{45}$ may prevent the protective coating from dissolving until the microspheres reach the distal small intestine or even the colon. As a result, the colonic epithelium may be susceptible to injury by release of massive quantities of proteases. Intact porcine enzymes would be capable of penetrating the submucosa, causing local damage or forming immune complexes with circulating antibodies. Thus the aetiopathogenesis of fibrosing colonopathy may be similar to that of other immune complex diseases such as glomerulonephritis. ${ }^{28}$ The presence of eosinophilic infiltrationwhich has consistently been observed in the colonic submucosa of affected cases - and the observation that the pathological lesion may progress even when pancreatic enzymes are discontinued or greatly reduced ${ }^{14}$ provide $^{15}$ additional support for an immunologically mediated mechanism. However, in order to show conclusively that protease or immune complex mediated damage is involved in the pathogenesis of fibrosing colonopathy, additional studies should be undertaken. These might include immunohistochemical localisation of antigen or antigen-antibody complex deposition in colonic specimens from patients with fibrosing colonopathy or from an appropriate animal model.

Fibrosing colonopathy is more prevalent at an early age. In general, the diagnosis is established between seven and 15 months after starting treatment with high doses of enzymes. In a previous study from our unit, antiporcine trypsin IgG was not detected in control subjects, nor in cystic fibrosis patients with pancreatic sufficiency who had not received pancreatic enzymes. ${ }^{18}$ Antiporcine trypsin IgG concentrations were increased in patients with cystic fibrosis receiving pancreatic enzymes, but there was no association between the duration of enzyme treatment and the IgG response. However, most of the cystic fibrosis patients studied in the previous report were much older and had been receiving enzymes for considerably longer. In the current study, we deliberately selected cystic fibrosis infants who were diagnosed at birth because of meconium ileus in order to evaluate age related responses to the ingestion of porcine enzymes. After the introduction of enzymes, most patients showed a marked antigenic response to porcine trypsin, the peak serum concentration of antiporcine trypsin IgG coinciding with the average time of clinical presentation of reported cases of fibrosing colonopathy in other cystic fibrosis centres. ${ }^{6-12}$

With only one exception, the patients evaluated in this study were not receiving enzyme doses that have been associated with an increased risk of fibrosing colonopathy. Furthermore, when expressed in units of enzyme activity per kg body weight, the patients were receiving fairly uniform doses of enzymes at all ages. For these reasons, we did not expect to identify a correlation between enzyme dose and the extent of the immunological response. Thus in future studies it would be prudent to evaluate the extent of the immune response in patients receiving higher doses of enzymes.
Although our study targeted porcine trypsin as a marker of response, other porcine enzymesincluding amylases, lipases, and other proteases-would be expected to induce a similar immunological effect.

In conclusion, we have shown that a young patient cohort with cystic fibrosis and pancreatic insufficiency developed raised antiporcine trypsin IgG concentrations in response to ingestion of porcine enzymes. The peak elevation occurred 7-12 months after introduction of enzyme treatment, which coincides with the onset of fibrosing colonopathy in several clinical reports. ${ }^{6-12}$ Thus local injury induced by massive quantities of pancreatic proteases or immune mediated mechanisms may be responsible for the pathological changes in fibrosing colonopathy.

Supported by a grant in aid from the Canadian Cystic Fibrosis Foundation. JL was supported by the Canadian Cystic Fibrosis Foundation Summer Student Programme

1 Welsh MJ, Tsui LC, Boat TF, Beaudet AL. Cystic fibrosis. In: Scriver CR, Beaudet AL, Sly WS, Valle D, eds. The metabolic and molecular bases of inherited disease. USA: McGraw-Hill Inc, 1995:3799-876.

2 Durie PR, Forstner GG. Pathophysiology of the exocrine pancreas in cystic fibrosis. FR Soc Med 1989; 82(suppl 16): 2-10.

3 DiMagno EP, Malagelada JR, Go VLW, Moertel CG. Fate of orally ingested enzymes in pancreatic insufficiency: comparison of two dosage schedules. N Engl f Med 1977;296: parison of th18-22.

4 Robinson PJ, Smith AL, Sly PD. Duodenal pH in cystic fibrosis and its relationship to fat malabsorption. Dig Dis Sci 1990; 35:1299-304.

5 Barraclough M, Taylor CJ. Twenty-four hour ambulatory gastric and duodenal $\mathrm{pH}$ profiles in cystic fibrosis: effect of duodenal hyperacidity on pancreatic enzyme function and fat absorption. F Pediatr Gastroenterol Nutr 1996;23:45-50.

6 Smyth RL, van Velzen D, Smyth AR, Lloyd DA, Heaf DP. Strictures of ascending colon in cystic fibrosis and high-strength pancretic enzymes. Lancet 1994;343:85-6.

7 Oades PJ, Bush A, Ong PS, Brereton RJ. High-strength pancreatic enzyme supplements and large bowel stricture in cystic fibrosis [letter]. Lancet 1994;343:109.

8 Campbell CA, Forrest J, Musgrove C. High-strength pancreatic enzyme supplements and large bowel stricture in cystic fibrosis [letter]. Lancet 1994;343:109.

9 Mahony MJ, Corcoran M. High-strength pancreatic enzymes [letter]. Lancet 1994;343:599-600.

10 Briars GL, Griffiths DM, Moore IE, Williams PH, Johnson K, Rolles CJ. High-strength pancreatic enzymes [letter]. Kancet 1994;343:600.

11 Knabe N, Zak M, Hansen A, et al. Extensive pathological changes of the colon in cystic fibrosis and high-strength pancreatic enzymes [letter]. Lancet 1994;343:85-6.

12 Pettei MJ, Leonidas JC, Levine JJ, Gorvoy JD. Pancolonic disease in cystic fibrosis and high-dose pancreatic enzyme therapy. F Pediatr 1994;125:587-9

13 Zerin JM, Kuhn-Fulton J, White SJ, et al. Colonic strictures in children with cystic fibrosis. Pediatr Radiol 1995;194: 223-6.

14 Schwarzenberg SJ, Wielinski CL, Shamieh I, et al. Cystic fibrosis-associated colitis and fibrosing colonopathy. F Pediatr 1995;127:565-70.

15 Borowitz DS, Grand RJ, Durie PR, and the Consensus Committee. Use of pancreatic enzyme supplements for patients with cystic fibrosis in the context of fibrosing colonopathy. F Pediatr 1995;127:681-4.

16 Smyth RL, Ashby D, O'Hea U, et al. Fibrosing colonopathy in cystic fibrosis: results of a case-control study. Lancet in cystic fibrosis: 1 .

17 FitzSimmons S, Burkhart G, Borowitz D, et al. High dose pancreatic enzyme supplements and fibrosing colonopathy in children with cystic fibrosis. $N$ Engl 7 Med 1997;18: 1283-9

18 Couper R, Lichtman S, Cleghorn G, del Castillo V, Durie P. Serum immunoglobulin $\mathrm{G}$ directed against porcine trypsin in pancreatic insufficient cystic fibrosis patients receiving pancreatic enzyme supplements. Pancreas 1992;6:558-63.

19 Udall JN, Walker, WA. The physiologic and pathologic transport of macromolecules across the intestinal tract. 7 Pediatr Gastroenterol Nutr 1982;1:295-301.

20 Udall JN, Walker WA. Mucosal defense mechanism. In: Marsh $\mathrm{MN}$, ed. Immunopathology of the small intestine. London: John Wiley and Sons, 1987:3.

21 Paganelli R, Levinsky RJ. Solid phase radioimmunoassay for detection of circulating food protein antigens in human detection of circulating food protein antigens

22 Kilshaw PJ, Cant AJ. The passage of maternal dietary Kilshaw PJ, Cant AJ. The passage of maternal dietary
proteins into human breast milk. Int Arch Allergy Appl Immunol 1984;75:8-15. 
23 Mack DR, Flick JA, Durie PR, Rosenstein BJ, Ellis LE, Perman JA. Correlation of intestinal lactulose permeability with exocrine pancreatic dysfunction. 7 Pediatr 1992;120 696-701.

24 Udall JM. Development of gastrointestinal mucosal barrier, 2 . The effect of natural versus artificial feeding on intestina permeability to macromolecules. Pediatr Res 1981;15:245-

25 Udall JN, Bloch KJ, Walker WA. Transport of proteases across neonatal intestine and development of liver disease in infants with alpha-1 antitrypsin deficiency. Lancet 1982; i: $1441-3$.
26 Kimm MH, Hardin JA, Gall DG. Macromolecular transport in the rabbit colon [abstract]. Gastroenterology 1996; 110(suppl):A937.

27 Carlson JA, Barton Rogers B, Sifer RN, Hawkins HK, Finegold MJ, Woo SLC. Multiple tissues express alpha 1 -antitrypsin in transgenic mice and man. $\mathcal{F}$ Clin Invest 1988;82:26-36.

28 Wilson CB, Tang WW, Feng L, Xia Y, Ward DM. Renal diseases. In: Stites DP, Terr AI, Parslow TG, eds. Basic and clinical immunology. East Norwalk, Connecticut: Appleton and Lange, 1994:481-7. 